\title{
Immunostimulatory Effect of Phoenix Dactylifera Supplemented Diet on Aeromonas hydrophila Infected Clarias gariepinus
}

\author{
Tajudeen O. Oriade ${ }^{1}$, Omoniyi S. Alao ${ }^{2}$ and Funmilayo I. D. Afolayan ${ }^{1 *}$ \\ ${ }^{I}$ Cell Biology and Genetics Unit, Department of Zoology, University of Ibadan, Ibadan, Nigeria \\ ${ }^{2}$ Department of Microbiology, University of Ibadan, Ibadan, Nigeria
}

\begin{abstract}
*Correspondence should be addressed to Fumilayo I.D. Afolayan: fidifede@gmail.com
Received 26th February 2021; Revised 11th April 2021; Accepted 25th April 2021

(C) 2021 Oriade et al. Licensee Pan African Journal of Life Sciences an official publication of Faculty of Basic Medical Sciences, Ladoke Akintola University of Technology, Ogbomoso. This is an Open Access article distributed under the terms of the Creative commons Attribution License (https://creativecommons.org/licenses/BY/4.0), which permits unrestricted use, distribution, and reproduction in any medium, provided the original work is properly cited.
\end{abstract}

\begin{abstract}
Background: Phoenix dactylifera fruit has been widely reported for its effective anti-inflammatory properties. Therefore, the effect of $P$. dactylifera on immune responses was evaluated in Aeromonas hydrophila infected Clarias gariepinus.

Methods: $P$. dactylifera fruit powder was used as feed inclusion at 0 (control), 0.5, 1.0 and 2.0\% concentrations to the pelleted fish diet of $C$. gariepinus juveniles. A total of 75 fish were divided into four groups $(\mathrm{n}=15)$. The fish were fed with the formulated feed twice a day $(08: 00 \mathrm{~h}$ and 17:00 $\mathrm{h})$, and terminated $24 \mathrm{~h}$ before the commencement of the microbial inoculation with inactivated Aeromonas hydrophila bacteria. The fish were later challenged with active Aeromonas hydrophila after seven weeks of experimental feeding. Blood samples were collected from fish while haemagglutination and phagocytic assays were used to determine the antibody titres and phagocytic action of the immune cells, respectively. Then, the micronucleus assay was used to determine the chromosomal damage effect of Aeromonas hydrophila pathogen on exposed C. gariepinus.

Results: After the challenge, the groups fed with 0.5 and $2.0 \%$ date showed significantly $(\mathrm{p}<0.05)$ elevated level of immune responses with antibody titres of $231.49 \pm 77.06$ and $257.18 \pm 51.37$, and phagocytic activity values of $0.07 \pm 0.01$ and $0.04 \pm 0.00$, respectively. The clastogenic effect of $A$. hydrophila on theperipheral blood of infected $C$. gariepinus was observed, this was significantly reduced in $2 \% P$. dactylifera fed group. Also, increase white blood cell count was observed in the C. gariepinus group fed with $0.5 \%$ date supplement. A higher lymphoid organ index was also observed in fish fed with the supplemented diet, as compared to the control.
\end{abstract}

Conclusions: These results indicate that $P$. dactylifera fruit powder enriched diet showed an immune-boosting and reduction of the DNA damaging effect in bacteria-infected C. gariepinus

Keywords: Aeromonas hydrophila, Antibody titre, Clarias gariepinus, Phoenix dactylifera, Vaccination 


\section{INTRODUCTION}

The health of an organism largely depends on the competency of its immunity. The immune system has been shown to play a pivotal role in the aetiology and pathophysiological mechanisms underlying many diseases and so, over the years, have become a critical aspect of scientific research [1]. Kidney, thymus, spleen, liver, and mucosa-associated lymphoid tissues (MALT) such as the gut, gills and heart are important immune competent organs of fish [2]. These organs are part of the fish immune system, which constantly ensure that invading pathogens are destroyed [3]. During invasions, numbers of phagocytic cell such as monocytes, lymphocytes and neutrophils may increase or decrease according to the health status of the fish[4].

Heavy mortalities have been recorded in both cultured and wild fish as a result of bacterial disease infestation, most of which are naturally occurring saprophytes[5] $A$. hydrophila is a motile group of gram negative bacteria belonging to the family the Aeromonadaceae. They are widely distributed in aquatic as well as terrestrial organisms; grow rapidly in moderate temperature ranging between $20-45^{\circ} \mathrm{C}$, which makes fish one of the most vulnerable animals at risk of $A$. hydrophila infection [6]. Also, its highly variable pathogenesis allows $A$. hydrophila to release substantial amount of its extracellular product (ECP) and induce cytotoxic, cytolytic, and haemolytic and enterotoxic properties leading to aeromoniasis infection in fishes[7]. Clarias gariepinus is a freshwater fish that is widely available as culture fish in Nigeria, as well as throughout tropical Africa [8]. They are one of the culture fish of choice due to their adaptability to varied water conditions and their omnivorous feeding habit [9].

The use of synthetic antibiotics and chemotherapeutics have been touted as a major contributing factors to the growing lists of resistant pathogen and chemical induced environmental pollution. Outcomes of these products when used as vaccines are not always successful and their sustainable use has been reported as a great influence in the development of more pathogen resistant strains of micro-organisms affecting both juvenile and adult fish [10]. The need to curb excessive application of synthetic chemicals in fish culture due to risks caused to humans through consumption of chemical residues in food and antibiotic resistance being passed on to human pathogens, is necessary [11]. Therefore, the use of whole, parts and plant derived compounds (phytochemicals) in fish immunity has become a rapidly growing area of research.
Dietary use of Phoenix dactylifera (commonly known as date) has shown that it contains vitamins, dietary fibers, reduced fat and proteins that the human body requires. According to Baliga et al. [12], consumption of hundred grams of date can provide over $15 \%$ recommended daily allowance of the necessary trace elements such as zinc, selenium, copper, sodium, potassium, etc. Date fruit as well as its aqueous extract have been reported for the free radical scavenging activity, anti-mutagenic and antiinflammatory effects [12]. However, few studies have been carried out with focus on the immunomodulatory activities of date fruit and most of the literature available are basically with the extract and mice as model [13-16], and without clear understanding of the basic mechanism. Therefore, there is need to carry out studies on the immunomodulatory effects of date fruit supplementary diets in C. gariepinus.

\section{MATERIALS AND METHODS}

This research was conducted in the Cell Biology and Genetics Unit laboratory of the Department of Zoology, University of Ibadan (UI), Nigeria. The research was approved by Animal Care and Use Research Ethic Committee (UI- ACUREC) assigned Number is UIACUREC/18/0102

\subsection{Preparation of Aeromonas hydrophila Pathogen and Inoculation Procedure}

Aeromonas hydrophila pathogens cultured in nutrient broth following Biller-Takahashi et al. [17] was obtained from the Department of Microbiology, UI. Briefly, the bacteria cells obtained were suspended in Phosphate buffer saline. The suspensions were washed three times and spun for 3 minutes at $3000 \mathrm{rpm}$ in sterile PBS. The bacterial cells were then inactivated with $3 \%$ formalin treatment for 24 hours at room temperature, washed three times and diluted to $1.5 \times 10^{9} \mathrm{cfu} \mathrm{ml}^{-1}$ concentration in PBS medium using standard turbidimetric assay according to Biller-Takahashi et al. [17]. The effectiveness of the inactivation process was ascertained by culturing the suspension of $A$. hydrophila cells prepared and rate of colony formation compared with untreated cells.

\subsection{Experimental Design}

Freshly collected date fruits were purchased from Bodija market, sorted, and oven dried at $37^{\circ} \mathrm{C}$. The dried pulps were then pulverized into powder, dry-mixed at $0,0.5$, 1.0 and 2.0 percent concentrations with a formulated fish $\operatorname{diet}(3 \mathrm{~mm}$ pellets) as presented in Table 1 . 
Table 1. Formulation of Experimental Diets

\begin{tabular}{lllll}
\hline Ingredients (g) & \multicolumn{4}{l}{$\begin{array}{l}\text { Graded levels of P. dactylifera Fruit } \\
\text { Powder (\%) }\end{array}$} \\
\cline { 2 - 5 } & 0 & 0.5 & 1.0 & 2.0 \\
Soya bean meal & 25 & 25 & 25 & 25 \\
Date powder & 0 & 0.5 & 1.0 & 2.0 \\
Fish meal & 25 & 25 & 25 & 25 \\
Rice bran & 17.5 & 17 & 16 & 15.5 \\
Wheat bran & 17.5 & 17.5 & 17.5 & 17.5 \\
Bone meal & 3.0 & 3.0 & 3.0 & 3.0 \\
G. N. C & 10 & 10 & 10 & 10 \\
Premixes & 1.0 & 1.0 & 1.0 & 1.0 \\
Wheat flour & 1.0 & 1.0 & 1.0 & 1.0 \\
(binder) & & & & \\
Total & 100 & 100 & 100 & 100 \\
\hline
\end{tabular}

Clarias gariepinus juveniles acquired from the Fishery Department of Oyo State Ministry of Agriculture, Ibadan were acclimatized for 21 days in 50 litres white transparent plastic tanks. A total of sixty $C$. gariepinus was divided into four (4) groups (A-D) consisting of 15 fish/50litre tank with respect to Date supplemented (DS) feed concentrations, and inoculation, as follows: group A, fed on $0 \% \mathrm{DS}$; group $\mathrm{B}, 0.5 \% \mathrm{DS}$; group $\mathrm{C}$, fed on $1.0 \% \mathrm{DS}$, and; group D, 2.0\% DS. All the fish received $0.1 \mathrm{ml} A$. hydrophila pathogen via Intraperitoneal injection[17]. A separate group (NV) $(n=15)$, was not vaccinated to compare genetic damaging effect and phagocytic indices.
Experimental activities and procedures are presented in Table 2.

\section{Haematological analysis}

Three fish from each group were sampled for blood collection 2days after Active $A$ hydrophila bacterial challenge. Blood was collected from the caudal vein into an EDTA lithium tubes. Parameters such as red blood cell count (RBC), platelet count and total white blood cell count (WBC) were completed using the Neubauer haemocytometer[18]. The packed cell volume (PCV) and haemoglobin $(\mathrm{Hb})$ concentration values were determined by the microhaematocrit capillary tube and cyanomethaemoglobin methods as described by Hesser [19]. The differential leukocyte count (DLC) for lymphocytes, monocytes, eosinophil, neutrophil and basophil was determined using standard procedure[20].

\section{Serum Agglutinating Antibody Titre}

The heamaglutination assay was done as described by Afolayan et al.[21], using 96 well microtiter plates with round bottom wells. Briefly, a dilution of $1: 1(50 \mu \mathrm{L}$ of phosphate buffer: $50 \mathrm{~mL}$ of serum) was prepared in the first rows of wells and subsequently followed by twofold serial dilutions, which was completed by adding 50 $\mu \mathrm{L}$ of diluted serum into the remaining wells with $50 \mu \mathrm{L}$ of phosphate buffer. Subsequently, $50 \mu \mathrm{L}$ of formalin killed $A$. hydrophila $(1 \times 109 \mathrm{cfu})$ suspension was added to each well after which the microtiter plate was covered with plastic film and incubated at room temperature. Plates were read after 3 and 18 hours. The agglutination

Table 2: Experimental Design for Immune Response

\begin{tabular}{|c|c|c|c|}
\hline S/No & Duration & Activity & Treatment/Procedures \\
\hline 1 & Day 0 & $\begin{array}{l}\text { Vaccination with inactivated } \\
\text { bacteria }\end{array}$ & $\begin{array}{l}\text { Intraperitoneal injection of } 0.1 \mathrm{ml} \text { of } 1.5 \times 10^{9} \mathrm{cfu} \mathrm{m}^{-1} \text { concentrated for- } \\
\text { malin killed Aeromonas hydrophila pathogen in PBS medium }\end{array}$ \\
\hline \multirow[t]{5}{*}{2} & Day 0-54 & Experimental Feeding & Group NV $-0 \%$ date supplemented feed \\
\hline & & & Group A $-0 \%$ date supplemented feed \\
\hline & & & Group B $-0.5 \%$ date supplemented feed \\
\hline & & & Group C $-1.0 \%$ date supplement feed \\
\hline & & & Group D $-2.0 \%$ date supplement feed \\
\hline 3 & Day 13 & Blood collection 1 & $\begin{array}{l}0.3-0.5 \mathrm{ml} \text { of peripheral blood samples collected from the caudal vein to } \\
\text { obtain serum for primary antibody titre determination. }\end{array}$ \\
\hline 4 & Day 30 & $\begin{array}{l}\text { Repeat Vaccination } \\
\text { (inactivated pathogen) }\end{array}$ & Same as day 0 \\
\hline 5 & Day 39 & Blood collection 2 & Same as day 13; obtain for secondary antibody titre. \\
\hline 6 & Day 50 & $\begin{array}{l}\text { Challenge } \\
\text { (active pathogen) }\end{array}$ & $\begin{array}{l}\text { Intraperitoneal injection of } 0.1 \mathrm{mlof} 1.5 \times 10^{9} \mathrm{cfu} \mathrm{m}^{-1} \text { concentrated live } \\
\text { Aeromonas hydrophila pathogen in PBS medium }\end{array}$ \\
\hline 7 & Day 52 & $\begin{array}{l}\text { Blood collection } 3 \text { and slides } \\
\text { preparation }\end{array}$ & $\begin{array}{l}\text { Blood collected for post-challenged antibody titre determination, slide } \\
\text { preparation for phagocytosis and micronucleus evaluation }\end{array}$ \\
\hline 8 & Day 52 & Sacrifice & Dissection and collection of organs; liver, gill, heart and kidney. \\
\hline 9 & Day $52-80$ & Post challenge observation & Observation for physiological and behavioural change \\
\hline
\end{tabular}


completion point was taken as the last serum dilution where at least $50 \%$ haemagglutination was visible and antibody titre was recorded as $\log 2$ of the reciprocal of the dilution factors.

\section{Determination of Phagocytic Activity and Index}

Phagocytic cells were identified following a modified

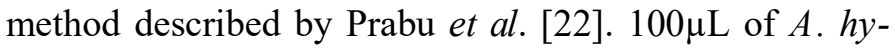
drophila $\left(1 \times 10^{9} \mathrm{cfu}\right)$ cells suspended in PBS $(\mathrm{pH} 7.2)$ was added to each of the five selected wells that already contained $100 \mu \mathrm{L}$ of blood samples which was then gently shaken to obtain a homogenous mixture and incubated for 20 minutes at room temperature. Smears were prepared using $5 \mu \mathrm{L}$ of the incubated mixture. Slides were air dried, fixed with $95 \%$ ethanol for 5 min and stained with Giemsa solution for 30 minutes.

A total of one hundred monocytes and neutrophils; numbers of phagocytizing cells as well as the amount of bacteria engulfed by the phagocyte were counted and recorded, from each smear.

\section{Determination of $\boldsymbol{A}$. hydrophila Genomic Damage Induction}

Three fish were selected from each of the treatment groups. From each fish, two slides were prepared. The smears were fixed for 20 minutes in absolute methanol, air-dried and then subjected to $10 \%$ Giemsa solution for 30 minutes. Any small, circular or ovoid, non-refractile chromatin bodies showing a similar stain pattern as the central nucleus was referred to as Micro-Nucleus (MN) [23]. Nuclear Aberrations (NA) were categorized following Carrasco et al. (1990) description. Briefly, cells with two nuclei were recorded as binucleated. From each group, 1000 cells were scored under $1000 \times$ magnification. Frequencies of $\mathrm{MN}$ and NA were expressed per 1000 cells (\%). Organ coefficient (relative organ weight) and other growth parameters were calculated in accordance with Kumari and Sahoo [24], as follows:

Feed consumption $=$ Unconsumed dried feed-Total weight of feed offered

Weight gain $(\%)=\frac{\text { Final weight }(g) \text { - Initial weight }(g)}{\text { Initial weight }(g)} \frac{100}{1}$

Feed conversion ratio $(g)=\frac{\text { Feed intake }(g)}{\text { Wet weight gain }(g)}$

Protein efficiency ratio $(g)=\frac{\text { Wet weight gain }(g)}{\text { Protein intake }(g)}$

Specific growth rate $(\%)=\frac{\log \text { e final }(g)-\text { Log e initial weight }(g)}{\text { Number of days }} \times \frac{100}{\mathbf{1}}$

Organ coefficient $(\%)=\frac{\text { Absolute organ weight }(g)}{\text { Body weight of animal }(g)} \times \frac{100}{1}$

\subsection{Statistical Analysis}

Numerical values were expressed as a Mean \pm Standard error of mean $(\mathrm{M} \pm \mathrm{SEM})$. Statistical analysis of the means of expression data among the four treatment groups were performed using one-way Analysis of variance (ANOVA) followed by Duncan's Multiple Range test. Analyses were performed using Microsoft Office Excel v 17.1 for Windows 10, SPSS 21.0.0 (Chicago, USA) for Windows and Graphpad Prism version 5.0 1. The effect of $P$. dactylifera fruit powder on immune response in $C$. gariepinus infected with $A$. hydrophila pathogen is presented as antibody titre $\left(\log _{2 x+1}\right)$.

\section{RESULTS}

\subsection{Effect of $P$. dactylifera Fruit Powder on Growth and Feed Efficiency}

Clarias gariepinus juveniles fed on graded levels of test diets that contain $0.5 \%, 1.0 \%$ and $2 \%$ concentrations of $P$. dactylifera as feed additive for 8 weeks showed no significant difference $(\mathrm{p}<0.05)$ on feed consumption, feed conversion and protein efficiency ratio when compared to the control during the feeding trial (Table 3), however, $1.0 \%$ date supplement showed higher mean values for feed consumption (29.89), feed conversion (1.57) and protein efficiency ratio $(0.47)$.

Table 3: Effect of $P$. dactylifera Fruit Powder on Weight Gain in C. gariepinus Juveniles.

\begin{tabular}{llll}
\hline Treatment & Initial & Final & $\begin{array}{l}\text { Weight } \\
\text { Change }\end{array}$ \\
$\begin{array}{l}0 \% \text { date sup- } \\
\text { plement } \\
\text { (control) }\end{array}$ & $15.84 \pm 0.67$ & $17.76 \pm 0.36^{\mathrm{abc}}$ & $1.92 \pm 0.36^{\mathrm{ab}}$ \\
$\begin{array}{l}0.5 \% \text { date } \\
\text { supplement }\end{array}$ & $14.82 \pm 0.67$ & $16.87 \pm 0.34^{\mathrm{ab}}$ & $2.05 \pm 0.34^{\mathrm{ab}}$ \\
$\begin{array}{l}1.0 \% \text { date } \\
\text { supplement }\end{array}$ & $15.83 \pm 0.80$ & $18.95 \pm 0.48^{\mathrm{b}}$ & $3.12 \pm 0.48^{\mathrm{b}}$ \\
$\begin{array}{l}2.0 \% \text { date } \\
\text { supplement }\end{array}$ & $14.83 \pm 0.56$ & $18.14 \pm 0.63^{\mathrm{bc}}$ & $3.31 \pm 0.36^{\mathrm{b}}$ \\
\hline
\end{tabular}

Mean $( \pm$ SEM) values with different alphabet are significantly different at $(\mathrm{p}<0.05)$ as determined by Duncan's tests.

Effect of $P$. dactylifera fruit powder on weight gain (Table 3) showed that the control $(1.92 \pm 0.36)$ was significantly lower than $1.0 \% \quad(3.12 \pm 0.48)$ and $2.0 \%$ (3.31 \pm 0.36$)$ fish groups. Also, result shown in Table 4 revealed an obvious increase in growth rate, specific 
growth rate and length increase in $1.0 \%(3.12 \pm 0.48$, $16.37 \pm 5.07$ and $0.15 \pm 0.02)$ and $2.0 \% \quad(3.31 \pm 0.63$, $22.32 \pm 4.28$ and $0.16 \pm 0.03)$ groups, relative to control $(1.92 \pm 0.36,12.12 \pm 2.33$ and $0.10 \pm 0.02)$.

Table 4: Effect of $P$. dactylifera Fruit Powder on Growth Indices of $C$. gariepinus Juveniles

\begin{tabular}{|c|c|c|c|c|}
\hline Treatment & $\begin{array}{l}\text { Growth } \\
\text { Rate }\end{array}$ & $\begin{array}{l}\text { Specific } \\
\text { Growth } \\
\text { Rate }\end{array}$ & $\begin{array}{l}\text { Length } \\
\text { Increase }\end{array}$ & $\begin{array}{l}\text { Specific } \\
\text { Length } \\
\text { Increase }\end{array}$ \\
\hline $\begin{array}{l}0 \% \text { date } \\
\text { supplement } \\
\text { (control) }\end{array}$ & $\begin{array}{l}1.92 \pm \\
0.36^{\mathrm{ab}}\end{array}$ & $\begin{array}{l}12.12 \pm \\
2.33^{\mathrm{ab}}\end{array}$ & $\begin{array}{l}0.10 \pm \\
0.02^{\mathrm{ab}}\end{array}$ & $\begin{array}{l}7.13 \pm \\
3.01\end{array}$ \\
\hline $\begin{array}{l}0.5 \% \text { date } \\
\text { supplement }\end{array}$ & $\begin{array}{l}2.05 \pm \\
0.35^{\mathrm{ab}}\end{array}$ & $\begin{array}{l}13.83 \pm \\
2.34^{\mathrm{ab}}\end{array}$ & $\begin{array}{l}0.11 \pm \\
0.02^{\mathrm{ab}}\end{array}$ & $\begin{array}{l}4.92 \pm \\
2.10\end{array}$ \\
\hline $\begin{array}{l}1.0 \% \text { date } \\
\text { supplement }\end{array}$ & $\begin{array}{l}3.12 \pm \\
0.48^{\mathrm{b}}\end{array}$ & $\begin{array}{l}16.37 \pm \\
5.07^{\mathrm{b}}\end{array}$ & $\begin{array}{l}0.15 \pm \\
0.02^{b}\end{array}$ & $\begin{array}{l}7.19 \pm \\
4.54\end{array}$ \\
\hline $\begin{array}{l}2.0 \% \text { date } \\
\text { supplement }\end{array}$ & $\begin{array}{l}3.31 \pm \\
0.63^{b}\end{array}$ & $\begin{array}{l}22.32 \pm \\
4.28^{\mathrm{b}}\end{array}$ & $\begin{array}{l}0.16 \pm \\
0.03^{b}\end{array}$ & $\begin{array}{l}11.65 \pm \\
3.96\end{array}$ \\
\hline
\end{tabular}

Mean $( \pm$ SEM) values with different alphabet are significantly different at $(\mathrm{p}<0.05)$ as determined by Duncan's tests.

\subsection{Effect of $P$. dactylifera Fruit Powder on Haemato- logical Parameters}

The haematological parameters are summarized in Table 5. Results showed no significant variations $(p<0.05)$ in packed cell volume (PCV), red blood cell counts (RBCs), and haemoglobin (HB) values among all inclusion levels or in relation to the control groups. Results in Figure 2 shows a significant increase in white blood cell (WBC) counts for $0.5 \%(16.56 \pm 6.33)$ when compared to the con-

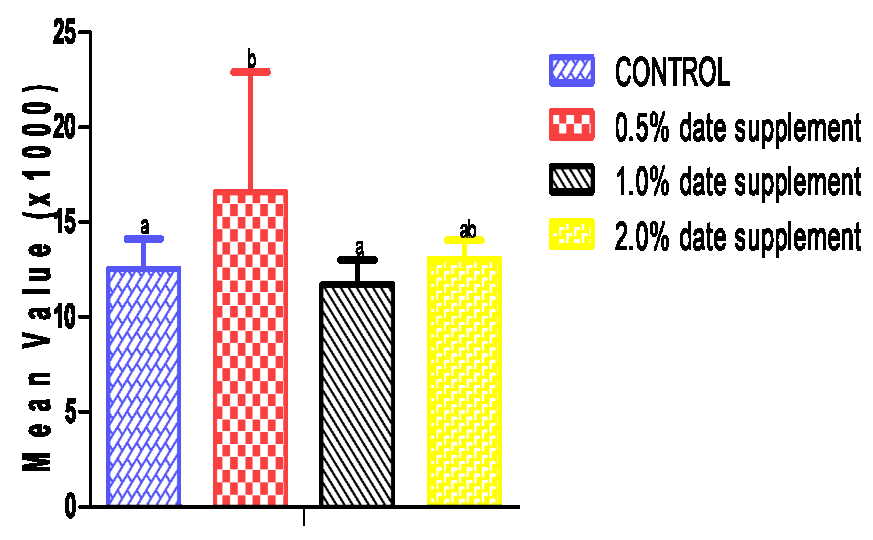

\section{Treatment groups}

Figure 1. Effect of Feed Supplemented with $P$. dactylifera Fruit Powder on White Blood Cells (WBC) of C. gariepinus juveniles.

Mean $( \pm$ SEM $)$ values with different alphabet significantly different $(p<0.05)$ as determined by Duncan's tests.

trol group (12.50 \pm 1.62$)$. It is interesting to note that platelet cells for the $2.0 \%(9.17 \pm 1.78)$ date was lower compared to the control $(11.03 \pm 1.60)$.

\subsection{Effect of $P$. dactylifera Fruit Powder on Organ Index}

The effect of date fruit powder on lymphoid organs relative to net body weight is shown in Table 6. Significantly higher index was recorded for liver in $0.5 \%(1.52 \pm 0.31)$ and $2.0 \%(1.70 \pm 0.06)$ treatment groups than $1.0 \%$ date supplement $(1.25 \pm 0.08)$ and control $(1.25 \pm 0.32)$ groups. While, $0.5 \%(0.37 \pm 0.02)$ and $1.0 \%(0.34 \pm 0.05)$ treatment

Table 5: Effect of P. dactylifera Fruit Powder on Haematological Parameters

\begin{tabular}{|c|c|c|c|c|c|c|c|c|c|c|}
\hline \multirow{2}{*}{ Treatments } & \multicolumn{10}{|c|}{ Haematological Parameters } \\
\hline & PCV & $\operatorname{PLT}\left(10^{4}\right)$ & RBC & HB & WBC $\left(10^{3}\right)$ & LYM & NUT & MON & $\mathrm{EO}$ & $\mathrm{BA}$ \\
\hline \multirow{2}{*}{$\begin{array}{l}0 \% \text { date sup- } \\
\text { plement } \\
\text { (control) }\end{array}$} & $18.67 \pm$ & $11.03 \pm$ & $1.24 \pm$ & $6.10 \pm$ & $12.50 \pm$ & $63.33 \pm$ & $27.00 \pm$ & $3.33 \pm$ & $5.00 \pm$ & $0.67 \pm$ \\
\hline & $1.86^{\mathrm{a}}$ & $1.60^{\mathrm{a}}$ & 0.06 & 0.70 & $1.62^{\mathrm{a}}$ & 0.88 & 0.58 & 0.88 & 1.00 & 0.33 \\
\hline \multirow{2}{*}{$\begin{array}{l}0.5 \% \text { date } \\
\text { supplement }\end{array}$} & $19.67 \pm$ & $10.23 \pm$ & $1.29 \pm$ & $6.17 \pm$ & $16.56 \pm$ & $55.00 \pm$ & $37.00 \pm$ & $4.00 \pm$ & $4.00 \pm$ & $0.00 \pm$ \\
\hline & $1.20^{\mathrm{a}}$ & $2.05^{\mathrm{a}}$ & 0.08 & 0.52 & $6.33^{\mathrm{b}}$ & 3.21 & 4.04 & 0.58 & 1.15 & 0.00 \\
\hline \multirow{2}{*}{$\begin{array}{l}1.0 \% \text { date } \\
\text { supplement }\end{array}$} & $17.33 \pm$ & $11.36 \pm$ & $1.13 \pm$ & $4.83 \pm$ & $11.67 \pm$ & $56.00 \pm$ & $37.67 \pm$ & $2.67 \pm$ & $4.00 \pm$ & $0.33 \pm$ \\
\hline & $0.88^{\mathrm{a}}$ & $1.34^{\mathrm{a}}$ & 0.05 & 0.38 & $1.35^{\mathrm{a}}$ & 3.06 & 2.84 & 0.33 & 0.58 & 0.33 \\
\hline \multirow{2}{*}{$\begin{array}{l}2.0 \% \text { date } \\
\text { supplement }\end{array}$} & $17.33 \pm$ & $9.17 \pm$ & $1.17 \pm$ & $5.67 \pm$ & $13.05 \pm$ & $60.33 \pm$ & $31.33 \pm$ & $2.67 \pm$ & $5.33 \pm$ & $0.33 \pm$ \\
\hline & $0.88^{\mathrm{a}}$ & $1.78^{\mathrm{a}}$ & 0.17 & 0.03 & $0.99^{\mathrm{ab}}$ & 2.60 & 3.48 & 0.67 & 1.20 & 0.33 \\
\hline
\end{tabular}

Mean $( \pm$ SEM) values with different alphabet are significantly different at $(\mathrm{p}<0.05)$ as determined by Duncan's test.

Parameters: PCV = Packed Cell Volume, RBC $=$ Red Blood cell Count, HB $=$ Haemoglobin, WBC $=$ White Blood cell Count, LYM = Lymphocytes, NUT = Neutrophil, MON = Monocyte, EO = Eosinophil, BA = Basophil, PLT $=$ Platelets. 
Table 6. Effect of $P$. dactylifera Fruit Powder on Organ Indices

\begin{tabular}{|c|c|c|c|c|c|c|c|c|c|}
\hline \multirow{3}{*}{$\begin{array}{l}\text { Treat- } \\
\text { ments }\end{array}$} & \multirow{3}{*}{$\begin{array}{l}\text { Net Body } \\
\text { Weight } \\
\text { Change }\end{array}$} & \multicolumn{8}{|c|}{ Organ Weight and index } \\
\hline & & Liver & & Kidney & & Gills & & Heart & \\
\hline & & $\begin{array}{l}\text { Absolute } \\
\text { Weight }\end{array}$ & $\begin{array}{l}\text { Organ In- } \\
\text { dex }\end{array}$ & $\begin{array}{l}\text { Absolute } \\
\text { Weight }\end{array}$ & Organ Index & $\begin{array}{l}\text { Absolute } \\
\text { Weight }\end{array}$ & $\begin{array}{l}\text { Organ } \\
\text { Index }\end{array}$ & $\begin{array}{l}\text { Absolute } \\
\text { Weight }\end{array}$ & $\begin{array}{l}\text { Organ } \\
\text { Index }\end{array}$ \\
\hline $\begin{array}{l}0 \% \text { date } \\
\text { supplement } \\
\text { (control) }\end{array}$ & $27.80 \pm 2.46$ & $0.37 \pm 0.11$ & $1.25 \pm 0.32^{\mathrm{a}}$ & $0.07 \pm 0.01^{\mathrm{a}}$ & $0.25 \pm 0.05^{\mathrm{ab}}$ & $0.90 \pm 0.17$ & $3.16 \pm 0.39$ & $0.03 \pm 0.00$ & $0.11 \pm 0.00$ \\
\hline $\begin{array}{l}0.5 \% \text { date } \\
\text { supplement }\end{array}$ & $27.23 \pm 3.08$ & $0.43 \pm 0.13$ & $1.52 \pm 0.31^{\mathrm{ab}}$ & $0.09 \pm 0.01^{\mathrm{ab}}$ & $0.37 \pm 0.02^{\mathrm{bc}}$ & $0.78 \pm 0.12$ & $2.86 \pm 0.31$ & $0.04 \pm 0.01$ & $0.14 \pm 0.01$ \\
\hline $\begin{array}{l}1.0 \% \text { date } \\
\text { supplement }\end{array}$ & $25.97 \pm 2.67$ & $0.33 \pm 0.05$ & $1.25 \pm 0.08^{\mathrm{a}}$ & $0.09 \pm 0.01^{\mathrm{ab}}$ & $0.34 \pm 0.05^{\mathrm{abc}}$ & $0.94 \pm 0.07$ & $3.66 \pm 0.78$ & $0.03 \pm 0.00$ & $0.10 \pm 0.00$ \\
\hline $\begin{array}{l}2.0 \% \text { date } \\
\text { supplement }\end{array}$ & $29.50 \pm 1.76$ & $0.50 \pm 0.03$ & $1.70 \pm 0.06^{\mathrm{ab}}$ & $0.06 \pm 0.00^{\mathrm{a}}$ & $0.21 \pm 0.02^{\mathrm{a}}$ & $0.87 \pm 0.08$ & $2.98 \pm 0.43$ & $0.13 \pm 0.09$ & $0.44 \pm 0.33$ \\
\hline
\end{tabular}

Mean $( \pm$ SEM $)$ values with different alphabet are significantly different at $(\mathrm{p}<0.05)$ as determined by Duncan's tests

groups were observed to be significantly higher than the $2.0 \%$ fish group $(0.21 \pm 0.02)$ and control $(0.25 \pm 0.05)$ groups for the kidney.

\section{Effect of $P$. dactylifera Fruit Powder on Immune Re- sponse}

Figure 2 presents the effect of P. dactylifera fruit powder on immune response in $\mathrm{C}$. gariepinus infected with $\mathrm{A}$. hydrophila pathogen. There was a progressive increase observed for titres values (primary and secondary antibody) obtained across all treatment groups. The primary antibody titres obtained were higher for $1.0 \%$ $(25.98 \pm 6.42)$ and $2.0 \%(25.98 \pm 6.42)$ fish groups; $0.5 \%$ $(141.58 \pm 84.22)$ and $1 \%(103.05 \pm 25.68)$; while the sec-

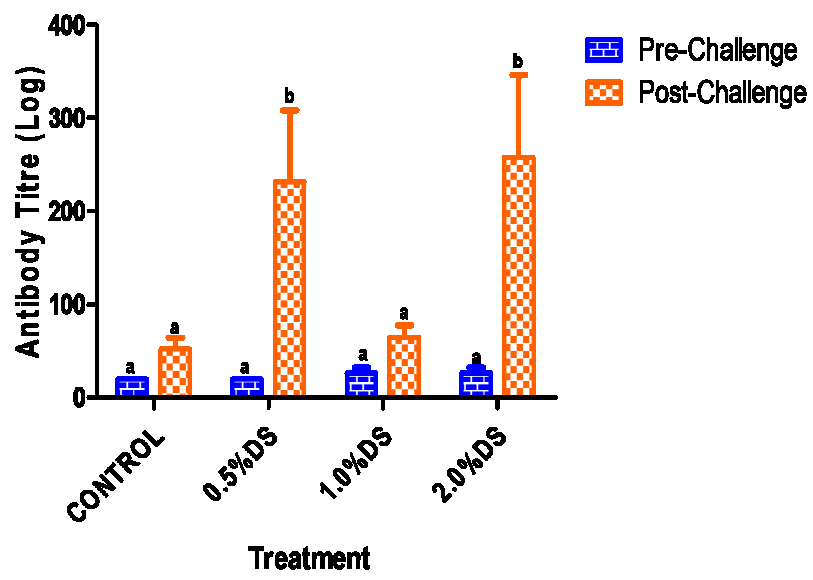

Figure 3. Pre-Challenge and Post-Challenge Antibody Titre.

Mean $( \pm$ SEM) values with different alphabet are significantly different $(\mathrm{p}<0.05)$ as determined by Duncan's test. $0.5 \%$ DS $=0.5 \%$ Date Supplement, $1.0 \%$ DS $=1.0 \%$ Date Supplement, $2.0 \%$ DS $=2.0 \%$ Date Supplement ondary antibody titres revealed, $0.5 \%$ (231.50土77.06) and $2.0 \%(257.18 \pm 51.37)$ experiments compared to control (16.35 \pm 3.21 and $51.67 \pm 12.84$, respectively).

\subsection{Effect of $P$. dactylifera on the Genetic Damaging Impact of A. hydrophila pathogen}

The frequencies of MN, NA, and Total aberration (TA) obtained for fish infected with $A$. hydrophilaas presented in Table 8 showed contrasting trends in all of the highlighted abnormalities as reported for the post-challenge and pre-challenge analysis. There was a dose-dependent increase in abnormalities for the pre-challenge, while an alternate reduction in abnormalities was observed across all the treatment groups for the post-challenge analysis.

\subsection{Phagocytic activity and index}

Table 9 presents the summary of phagocytic activity and index. The serum phagocytic activity exhibited a reducing trend and increasing trend for phagocytic index, in relation to the increase in date fruit powder incorporated diet. A clear significant difference $(\mathrm{p}<0.05)$ of phagocytic activity was observed in the $0.5 \%(0.07 \pm 0.01)$ fish group and that of phagocytic index in the $1.0 \%$ $(2.68 \pm 0.25)$ fish group as compared to the nonvaccinated fish group $(0.03 \pm 0.01$ and $1.22 \pm 0.12$, respectively) (Figure 6).

\section{DISCUSSION}

Aeromonas hydrophila is a significant cause of bacterial infections in fishes, including catfish (Clarias gariepinus), carp (C. carpio), largemouth bass (Micropterus 
Oriade et al Pan African Journal of Life Sciences (2021):5(1):214-224

Table 7. Effect of $P$. dactylifera Fruit Powder on Immune Response

\begin{tabular}{|c|c|c|c|}
\hline \multirow[t]{2}{*}{ Treatment } & \multicolumn{2}{|c|}{ Pre-challenged Antibody Titre } & \multirow{2}{*}{$\begin{array}{l}\text { Post-challenged Antibody Titre } \\
\text { Challenge }\end{array}$} \\
\hline & Primary & Secondary & \\
\hline No vaccination (NV) & $21.17 \pm 9.76^{\mathrm{a}}$ & $25.98 \pm 6.42^{\mathrm{a}}$ & $19.94 \pm 5.61^{\mathrm{a}}$ \\
\hline $0 \%$ date supplement (Control) & $16.35 \pm 3.21^{\mathrm{a}}$ & $51.67 \pm 12.84^{\mathrm{a}}$ & $51.67 \pm 12.84^{\mathrm{a}}$ \\
\hline $0.5 \%$ date supplement & $19.56 \pm 0.00^{\mathrm{a}}$ & $141.58 \pm 84.22^{b}$ & $231.49 \pm 77.06^{\mathrm{b}}$ \\
\hline $1.0 \%$ date supplement & $25.98 \pm 6.42^{\mathrm{a}}$ & $103.05 \pm 25.68^{\mathrm{b}}$ & $64.52 \pm 12.84^{\mathrm{a}}$ \\
\hline $2.0 \%$ date supplement & $25.98 \pm 6.42^{\mathrm{a}}$ & $38.83 \pm 0.00^{\mathrm{a}}$ & $257.18 \pm 51.37^{\mathrm{b}}$ \\
\hline
\end{tabular}

Mean $( \pm$ SEM) values with different alphabet are significantly different at $(\mathrm{p}<0.05)$ as determined by Duncan's test.

Table 8. Effect of $P$. dactylifera on the Genetic Damaging Impact of A. hydrophila pathogen in C. gariepinus

\begin{tabular}{|c|c|c|c|c|c|c|}
\hline \multirow[t]{3}{*}{ Treatment groups } & \multicolumn{6}{|c|}{ Cellular Abnormality } \\
\hline & \multicolumn{3}{|l|}{ Pre-Challenge } & \multicolumn{3}{|l|}{ Post-Challenge } \\
\hline & Micronucleus & Nuclear aber- & Total aberra- & Micronucleus & Nuclear aber- & Total aberration \\
\hline No vaccination (NV) & $4.00 \pm 1.63^{\mathrm{a}}$ & $\begin{array}{l}\text { ration } \\
14.00 \pm 4.76^{\mathrm{a}}\end{array}$ & $\begin{array}{l}\text { tion } \\
18.00 \pm 6.00^{\mathrm{ab}}\end{array}$ & $40.00 \pm 6.73^{\mathrm{a}}$ & $\begin{array}{l}\text { ration } \\
6.00 \pm 2.58^{\mathrm{ab}}\end{array}$ & $46.00 \pm 6.21^{b}$ \\
\hline $\begin{array}{l}0 \% \text { date supplement } \\
\text { (control) }\end{array}$ & $10.00 \pm 4.76^{\mathrm{a}}$ & $15.00 \pm 4.12^{\mathrm{ab}}$ & $25.00 \pm 7.72^{\mathrm{ab}}$ & $45.00 \pm 11.94^{\mathrm{b}}$ & $11.00 \pm 2.51^{b}$ & $56.00 \pm 4.32^{\mathrm{b}}$ \\
\hline $0.5 \%$ date supplement & $5.00 \pm 1.92^{\mathrm{a}}$ & $5.00 \pm 1.91^{\mathrm{a}}$ & $10.00 \pm 2.58^{\mathrm{a}}$ & $12.00 \pm 3.26^{\mathrm{a}}$ & $0.00 \pm 0.00^{\mathrm{a}}$ & $12.00 \pm 1.63^{\mathrm{a}}$ \\
\hline $1.0 \%$ date supplement & $8.00 \pm 2.83^{\mathrm{a}}$ & $23.00 \pm 3.41^{\mathrm{b}}$ & $31.00 \pm 2.51^{\mathrm{b}}$ & $8.00 \pm 2.82^{\mathrm{a}}$ & $3.00 \pm 1.91^{\mathrm{a}}$ & $11.00 \pm 3.78^{\mathrm{a}}$ \\
\hline $2.0 \%$ date supplement & $22.00 \pm 4.78^{\mathrm{b}}$ & $26.00 \pm 7.02^{b}$ & $47.00 \pm 3.41^{\mathrm{c}}$ & $11.00 \pm 1.91^{\mathrm{a}}$ & $2.00 \pm 1.15^{\mathrm{a}}$ & $13.00 \pm 2.51^{\mathrm{a}}$ \\
\hline
\end{tabular}

Mean $( \pm$ SEM) values with different alphabet are significantly different at $(\mathrm{p}<0.05)$ as determined by Duncan's tests.

salmoides), Nile tilapia (O. niloticus) and striped bass (Morone saxatilis) [6]. Medicinal plants have been suggested as a sustainable and natural growth-promoting alternative in fish [25]. In the present study, inclusion of date fruit powder especially at $2 \%$ showed significant effect on weight and length increase when compared to control. The positive trend of immunostimulation demonstrated by fish on date enriched diet is an indication that date fruit possesses the ability to aid digestion of feed for effective utilization without detrimental effects [12]. The current result agrees with previous findings, where $P$. dactylifera fruit exhibited growth-promoting effects [26,27].

The measurement of organ weights such as kidney, liver, gills and heart in relation to body weight can be directly associated with some environmental changes that act on the general status of health of the fish. In the present study fish fed with feed supplemented date fruit at different concentrations showed a slight significant increase in the index of all selected organs, beside the gills, when compared to control (Table 6). This may be an indication that the stress induced by $A$. hydrophila pathogens injected in the fish has over time induced morphological changes in the selected organs. This is, however, in contrast to reports of Ensibi et al. [28], Jordaan et al.[29] and Nwani et al.[30] that no significant effect was detected in fish organs exposed to pyrethroid, organophosphate and paraquat toxicants, respectively, when they were compared to control. Exposure to the bacterial pathogen may have altered some regulatory function of the immune system, thus, contribute to the observed physiological changes in the selected organs.

Different species of teleost including Clarias fish produce specific IgM-type natural antibodies against various antigens [31]. Significantly higher agglutination titre observed in the $2.0 \%$ and $0.5 \%$ treatment groups as compared to the control could be an indication that $P$. dactylifera fruit possess active immunostimulatory compounds. Selenium, carotenoids, quercetin, kaempferol and isorhamnetin are among the bioactive compounds present 
in date fruit [32] and that these compounds possess immunostimulatory effects, which may as well be accountable for the perceived effects in the current study. The present finding is in line with report of Yeasmin et al. [33] in Nile tilapia (O. niloticus) [34] where $2.0 \% \mathrm{~L}$. indica and fenugreek seed supplemented diets fed fish showed the highest immune response against $A$. hydrophila. This study result agrees with the finding of Ji et al. [34] where $0.5 \%$ dietary supplementation of powdered fruit of Massa medicata fed to red sea bream, Pargus major for 12 weeks observably activates the immune system of the fish. Perveen et al. [35], in their study also showed similar antibacterial action of $P$. dactylifera leaf and pit extracts against Streptococcus pyogenes.

In this experiment, $C$. gariepinus juvenile fed with date supplement showed a higher immune response than the control that was fed without date. The positive trend observed across all groups follows typical immunoglobulin response after primary and challenge immunization [36]. The post-challenge response observed may be as a result of the large numbers of memory cells produced after primary (pre-challenge) B-cell activation [37].

Phagocytes act as cellular scavengers and so, constitute an important part of the host defence system against infectious diseases [38]. Phagocytic ability of leukocytes such as monocyte against xenobiotic amoeboid movement or phagocytosis by neutrophil are well established [4]. Thus, higher amount of leukocytes comprising neutrophil, monocyte and lymphocyte observed in fish groups that were fed with date at $0.5 \%$ and $1.0 \%$ date supplement corroborates with findings of Thanomsit et al. [4].

An increase in phagocytic activity indicated the significant role of $P$. dactylifera enhancing the immune response. Similar finding has been reported in rainbow trout fed with $A$. sativum, L. perennis, M. indica, and $U$. dioica against $A$. hydrophila infection [33]. The free radical scavenging and antioxidant activities of lignin, selenium and phenolic compounds present in the date fruit may be responsible for the observed antimicrobial and phagocytic activity [32].

Haematology indices are key assumptions that can be used to evaluate the effects of dietary treatments on animals [4]. Blood parameters assessed, such as packed cell volume (PCV), haemoglobin (HB), and red blood cell counts (RBC's), although not statistically significant, could serve as an indication that $P$. dactylifera can be incorporated in diet to prevent anaemic condition. White blood cells (WBC) that circulate the blood in search of foreign particles are believed to increase quickly when infections occur, therefore the increase in number of WBC observed in infected fish (Figure 1) may serve as a defensive barrier against pathogenic attack [39]. The increased WBC counts recorded in the present study specify the immunostimulatory effect and anti-bacterial potential of $P$. dactylifera fruit [12].

According to Talpur et al. [39], when fish stop feeding as a result of disease or stress, a possible indication of this is low haematocrit (PCV \%) level. The decreased HB content in the fish (Table 5), may point to the fact that the fish were stressed as a result of the $A$. hydrophila infection. The present study agrees with Mason [40] that reported similar observation when $C$. gariepinus was subjected to a sub-lethal concentration of formalinas well as well as studies of Thanomsit et al. [4] on cytological alteration of leucocytes and Kumolosasi et al. [41] on immunostimulant activity of Magnifera indica leaf and Curcuma domestica rhizome in mice.

Micronucleus analysis has over time been used as a successful probe for detecting genomic damage in aquatic species [42]. The present study examines the level of $A$. hydrophila induced toxicity on the peripheral erythrocytes of $C$. gariepinus juvenile fed with varying levels of test diet and evaluated using the piscine MN assay. DNA damage arising from micronuclei formation likely contributes to immune activation $[43,44]$. Therefore, the significant increase in $2.0 \%$ group may be due to the level of immune reaction the test feed was able to stimulate in the pre-challenge. Furthermore, the contrasting reduction in significant difference observed in this same group for the post-challenge test (Table 8) might have arisen due to memory cells that aid rapid stimulation of immune response.

These results also showed that there is significant stimulation of genotoxic stress, which may be as a result of the release of extracellular product by $A$. hydrophila cells after injection[7]. The outcome in the current study is also similar to reports in previous studies $[23,42]$. The assertions that extracellular product can induce $\mathrm{MN}$ and NA observed in the peripheral erythrocytes of the $C$. gariepinus juveniles is corroborated by findings of Bartsch et al. [43], Gekara [45], and Harding et al. [44].

The effects of selenium in low concentration against carcinogens and mutagens as well as anthocyanins, proanthocyanidins, phenolics, and $\beta$ - carotene against mutagens have been reported[12]. Therefore, the cumulative 
effect of these components in the test substance may have been accountable for the observed reduction in effect of $A$. hydrophila pathogen after challenge.

In conclusion, the present study has shown that date fruit powder included as dietary supplement enhanced growth rate, immune response, phagocytic activity and phagocytic indexes which have collectively contributed to observed resistance against $A$. hydrophila pathogen in treated $C$. gariepinus. This study further demonstrated that $P$. dactylifera fruit powder as a food additive for C. gariepinus reduces cellular damage due to active $A$. hydrophila pathogens.

\section{Funding}

This research did not receive any specific grant from funding agencies in the public, commercial, or not-forprofit sectors.

\section{Authors' contributions}

TOO, Collected data, contributed to data, performed data analysis and wrote the paper. OSA, contributed to data and analysis. FIDA, conceived and designed the study, contributed to data and analysis and wrote the paper.

\section{Reference}

1. Netea MG, Schlitzer A, Placek K, Joosten LAB, Schultze JL. Innate and Adaptive Immune Memory: an Evolutionary Continuum in the Host's Response to Pathogens. vol. 25. 2019. https://doi.org/10.1016/j.chom.2018.12.006.

2. Kum C, Sekki S. The Immune System Drugs in Fish: Immune Function, Immunoassay, Drugs. Recent Adv. Fish Farms, 2011. https://doi.org/10.5772/26869.

3. Samaï HC, Rioult D, Bado-Nilles A, Delahaut L, Jubréaux $\mathrm{J}$, Geffard A, et al. Procedures for leukocytes isolation from lymphoid tissues and consequences on immune endpoints used to evaluate fish immune status: A case study on roach (Rutilus rutilus). Fish Shellfish Immunol 2018;74:190-204.https://doi.org/10.1016j.fsi.2017.12.040.

4. Thanomsit C, Ocharoen Y, Phakdee P. Histopathological and Cytological Alterations of Leukocytes in Hybrid Catfish Infected with Aeromonas sp . Collected from the Market in Surin Province. Ph01tci-Thaijoorg 2016:14-24.

5. Roberts RJ. The Bacteriology of Teleosts. In: Roberts RJ, editor. Fish Pathol., Oxford, UK: Wiley-Blackwell; 2012, p. 339-82. https://doi.org/10.1002/978 1118222942.ch8.

6. Abdel-Latif HM, Khafaga AF. Natural co-infection of cultured Nile tilapia Oreochromis niloticus with Aeromonas hydrophila and Gyrodactylus cichlidarum experi- encing high mortality during summer. Aquac Res 2020;51:1880-92.

7. Sahu I, Das BK, Marhual N, Samanta M, Mishra BK, Eknath AE. Toxicity of Crude Extracellular Products of Aeromonas hydrophila on Rohu, Labeo rohita (Ham.). Indian J Microbiol 2011;51:515-20. https:// doi.org/10.1007/s12088-011-0182-6.

8. Effiong MU, Isaac IN. Comparative study of the bacterial load and species diversity in the African catfish (Clarias gariepinus) cultured in contrasting aquaculture tanks in Uyo, Nigeria. Anim Res Int 2019;16:3443-9.

9. Dadebo E, Aemro D, Tekle-Giorgis Y. Food and feeding habits of the $\mathrm{A}$ frican catfish $\mathrm{C}$ larias gariepinus (B urchell, 1822)(P isces: $\mathrm{C}$ lariidae) in $\mathrm{L}$ ake $\mathrm{K}$ oka, $\mathrm{E}$ thiopia. Afr J Ecol 2014;52:471-8.

10. Kraemer SA, Ramachandran A, Perron GG. Antibiotic Pollution in the Environment: From Microbial Ecology to Public Policy. Microorganisms 2019;7:180. https:// doi.org/10.3390/microorganisms7060180.

11. Bankole OM, Nnamdi G, Ezeri O. Vom Journal of Veterinary Science Vol. 11, 2016: 1 - 12 2016;11:1-12.

12. Baliga MS, Baliga BRV, Kandathil SM, Bhat HP, Vayalil PK. A review of the chemistry and pharmacology of the date fruits (Phoenix dactylifera L.). Food Res Int 2011;44:1812-22.

13. Al-Farsi M, Alasalvar C, Morris A, Baron M, Shahidi F. Compositional and sensory characteristics of three native sun-dried date (Phoenix dactylifera L.) varieties grown in Oman. J Agric Food Chem 2005;53:7586-91.

14. Elhemeidy RMM, Lyrawati D, Widjajanto E. Date Fruit Extract (Phoenix dactylifera, Ajwa) Modulates NK Cells and TNF-Alpha in DMBA-Induced Mammary Cancer Sprague-Dawley Rats. J Trop Life Sci 2018;8:227-35.

15. Saafi EB, El Arem A, Issaoui M, Hammami M, Achour L. Phenolic content and antioxidant activity of four date palm (Phoenix dactylifera L.) fruit varieties grown in Tunisia. Int J Food Sci Technol 2009;44:2314-9. https:// doi.org/10.1111/j.1365-2621.2009.02075.x.

16. Tang ZX, Shi LE, Aleid SM. Date fruit: Chemical composition, nutritional and medicinal values, products. vol. 93 . 2013. https://doi.org/10.1002/jsfa.6154.

17. Biller-Takahashi JD, Montassier HJ, Takahashi LS, Urbinati EC. Proposed method for agglutinating antibody titer analysis and its use as indicator of acquired immunity in pacu, Piaractus mesopotamicus. Braz J Biol 2014;74:23842.

18. Dacie JV, Lewis SM. Practical haematology. 9th ed. Edinburgh: Churchill Livingstone (Is; 2001. 
19. Hesser EF. Methods for Routine Fish Hematology. Progress Fish-Cult 1960;22:164-71. https://doi.org/10.1577/ 1548-8659(1960)22[164:MFRFH]2.0.CO;2.

20. Baker RL, Mwamachi DM, Audho JO, Aduda EO, Thorpe W. Resistance of Galla and Small East African goats in the sub-humid tropics to gastrointestinal nematode infections and the peri-parturient rise in faecal egg counts. Vet Parasitol 1998;79:53-64. https://doi.org/10.1016/S0304-4017 (98)00151-4.

21. Afolayan FID, Erinwusi B, Oyeyemi OT. Immunomodulatory activity of curcumin-entrapped poly d,1 -lactic- co glycolic acid nanoparticles in mice. Integr Med Res 2018;7:168-75. https://doi.org/10.1016/j.imr.2018.02.004.

22. Prabu DL, Sahu NP, Pal AK, Dasgupta S, Narendra A. Immunomodulation and interferon gamma gene expression in sutchi cat fish, Pangasianodon hypophthalmus: Effect of dietary fucoidan rich seaweed extract (FRSE) on pre and post challenge period. Aquac Res 2016;47:199218. https://doi.org/10.1111/are.12482.

23. Alimba CG, Bakare AA. In vivo micronucleus test in the assessment of cytogenotoxicity of landfill leachates in three animal models from various ecological habitats. Ecotoxicology 2016;25:310-9.

24. Kumari J, Sahoo PK. Dietary immunostimulants influence specific immune response and resistance of healthy and immunocompromised Asian catfish Clarias batrachus to Aeromonas hydrophila infection. Dis Aquat Organ 2006;70:63-70. https://doi.org/10.3354/dao070063.

25. Rashidian G, Bahrami Gorji S, Farsani MN, Prokić MD, Faggio C. The oak (Quercus brantii) acorn as a growth promotor for rainbow trout (Oncorhynchus mykiss): growth performance, body composition, liver enzymes activity and blood biochemical parameters. Nat Prod Res 2020;34:2413-23.https://doi.org/10.1080/1478641 9.2018.1538994.

26. Awad E, Awaad A. Role of medicinal plants on growth performance and immune status in fish. vol. 67. 2017. https://doi.org/10.1016/j.fsi.2017.05.034.

27. Dada AA, Fagbohun AE. Effects of Dietary Supplementation of Date palm (Phoenix dactylifera L.) Seed on Milt Quality of African Catfish (Clarias gariepinus) Broodstocks 2018.

28. Ensibi C, Pérez-López M, Soler Rodríguez F, MíguezSantiyán MP, Yahya MND, Hernández-Moreno D. Effects of deltamethrin on biometric parameters and liver biomarkers in common carp (Cyprinus carpio L.). Environ Toxicol Pharmacol 2013;36:384-91. https://doi.org/10. 1016/j.etap.2013.04.019.

29. Jordaan MS, Reinecke SA, Reinecke AJ. Biomarker responses and morphological effects in juvenile tilapia Oreochromis mossambicus following sequential exposure to the organophosphate azinphos-methyl. Aquat Toxicol 2013;144-145:133-40. https://doi.org/10.1016/j.aquatox. 2013.10.007.

30. Nwani CD, Ejere VC, Onyeke CC, Chukwuka CO, Didigwu Nwani C, Ifeanyichukwu Ekwueme H, et al. Physiological effects of paraquat in juvenile African catfish Clarias gariepinus (Burchel 1822). J Coast Life Med 2014;3:35-43. https://doi.org/10.12980/jclm.3.2015jclm2014-0113.

31. Leal Y, Velazquez J, Hernandez L, Swain JK, Rodríguez AR, Martínez R, et al. Promiscuous T cell epitopes boosts specific IgM immune response against a P0 peptide antigen from sea lice in different teleost species. Fish Shellfish Immunol 2019;92:322-30. https://doi.org/10.1016/j.fsi. 2019.06 .018 .

32. Mahmud IA, Mirghani MES, Alkhatib MFR, Yusof F, Shahabuddin M, Rashidi O, et al. Nutrients depictions of Barhi date palm (Phoenix dactylifera L.) kernels. Int Food Res J 2017;24:325-34.

33. Yeasmin F, Hossain Md, Khatun A, Rahman M, Alam Md. Indian Lettuce Extract as Feed Additive Enhances Immunological Parameters in Mono-Sex Nile Tilapia against Aeromonas hydrophila. $\mathrm{Br} \mathrm{J}$ Pharm Res 2015;5:309-18. https://doi.org/10.9734/BJPR/2015/15436.

34. Ji SC, Jeong GS, Im GS, Lee SW, Yoo JH, Takii K. Dietary medicinal herbs improve growth performance, fatty acid utilization, and stress recovery of Japanese flounder. Fish Sci 2007;73:70-6. https://doi.org/10.1111/j.14442906.2007.01303.x.

35. Perveen K, Bokhari NA, Soliman DAW. Antibacterial activity of Phoenix dactylifera L. leaf and pit extracts against selected Gram negative and Gram positive pathogenic bacteria. J Med Plants Res 2012;6:296-300. https:// doi.org/10.5897/JMPR11.1380.

36. Coffman RL, Sher A, Seder RA. Vaccine adjuvants: putting innate immunity to work. Immunity 2010;33:492503.

37. Uribe C, Folch H, Enriquez R, Moran G. Innate and adaptive immunity in teleost fish: A review. vol. 56. 2011. https://doi.org/10.17221/3294-VETMED.

38. Nayak SK. Probiotics and immunity: A fish perspective. Fish Shellfish Immunol 2010;29:2-14. https://doi.org/10. 1016/j.fsi.2010.02.017.

39. Talpur AD, Munir MB, Mary A, Hashim R. Dietary probiotics and prebiotics improved food acceptability, growth performance, haematology and immunological parameters and disease resistance against Aeromonas hydrophila in snakehead (Channa striata) fingerlings. Aquaculture 2014;426-427:14-20. https://doi.org/10.1016jaquaculture. 2014.01.013. 
40. Mason CF. Biology of Freshwater Pollution. Third Edition. Department of Biology and Chemical Sciences. University of Essex: Longman Group UK; 1996.

41. Kumolosasi E, Ibrahim SNA, Shukri SMA, Ahmad W. Immunostimulant activity of standardised extracts of mangifera indica leaf and curcuma domestica rhizome in mice. Trop J Pharm Res 2018;17:77-84. https://doi.org/10.4314/ tjpr.v17i1.12.

42. Alimba CG, Ajiboye RD, Fagbenro OS. Dietary ascorbic acid reduced micronucleus and nuclear abnormalities in Clarias gariepinus (Burchell 1822) exposed to hospital effluent. Fish Physiol Biochem 2017;43:1325-35.

43. Bartsch K, Knittler K, Borowski C, Rudnik S, Damme M, Aden $\mathrm{K}$, et al. Absence of RNase $\mathrm{H} 2$ triggers generation of immunogenic micronuclei removed by autophagy. Hum Mol Genet 2017;26:3960-72.

44. Harding SM, Benci JL, Irianto J, Discher DE, Minn AJ, Greenberg RA. Mitotic progression following DNA damage enables pattern recognition within micronuclei. Nature 2017;548:466-70. https://doi.org/10.1038/nature23470.

45. Gekara NO. DNA damage-induced immune response: Micronuclei provide key platform. vol. 216. 2017. https:// doi.org/10.1083/jcb.201708069. 